\title{
John Stuart Mill: Market Socialist?
}

Helen McCabe

School of Politics and International Relations

University of Nottingham

Helen McCabe is Assistant Professor in Political Theory at the University of Nottingham. Most of her research has focused on John Stuart Mill's claim to be 'under the general designation of Socialist': her book John Stuart Mill: Socialist is forthcoming with McGill-Queens University Press. Since January 2020 she has been an AHRC Leadership Fellow, working on a project looking at the connection between forced marriage and modern slavery with the Rights Lab, a University of Nottingham Beacon of Research Excellence.

Compared to other elements of his political and economic thought, John Stuart Mill's claim to be 'under the general designation of Socialist' (Mill 1981, 239) has been largely ignored. (Though there is increasing current interest in his socialism and his egalitarianism (e.g. Baum 1998, 1999, 2007 and 2000; McCabe 2012, 2015, 2018, 2019a and 2019b; Persky 2016 and 2019; Turner 2019a and 2019b).) Where it has been acknowledged, it has generally been denied. ${ }^{1}$

There are three broad exceptions to this rule, which may overlap. The first is to treat Mill's socialism seriously, but to say that it was short-lived, an aberration in his otherwise liberal life lasting roughly 1848-1852 (e.g. Kurer 1992), or to acknowledge it, but to deny that it really poses a challenge for Mill's liberal credentials (e.g. Riley 1996; Miller 2003; Rawls 2001, 138-40 and 1972, 280). ${ }^{2}$ The second is to consider Mill's socialism historically, and link it to the 'utopian' socialism of William Thompson, Robert Owen, Henri Saint-Simon and Charles Fourier (e.g. Claeys 1987; Kurer 1992; Stafford 1998). Given the way in which 'utopian' socialism is often dismissed as not 'really' socialism, or not a form of socialism with contemporary relevance, this also serves to deradicalize Mill's ideas (see also Sarvasy 1985). The third has been to link Mill to 'market socialism' (e.g. Stafford 1998, 332-34; Gray 1995, 6; Baum 2007, 104; Ryan 2007, 164; Riley 1996, 39 and 65; Medearis 2005, 137), primarily because of his commitment to competition.

Mill's 'socialism' certainly involves exchanges between worker-cooperatives, and he felt that his belief that there were some advantages to competition separated him from most contemporary socialists (Mill 1965, 758-796). In this paper, I consider to what extent Mill's 'socialism' is 'market socialism' or even a 'socialism with markets'.

\footnotetext{
${ }^{1}$ See, for instance, Bain, 1882, 90; Capaldi, 2012, 125-144; Fredman and Gordon, 1967, 3-7; Hainds, 1946, 103-12; Losman, 1971, 84-104; Schapiro, 1943, 127-60; Flew, 1975; Duncan, 1973; Hollander, 1985, 179; Macpherson, 1977, 44-64; Reeves, 2007, 213; Schwartz, 1972, 165-92; Thomas, 1985, 190; Winch, 2009, 49-53.

2 I think we should read Mill as being consistently socialist (though with some changes to the precise content of is view) from around 1845, for reasons which are much too lengthy to go into here (though I explore them in detail elsewhere, particularly John Stuart Mill: Socialist (forthcoming, McGill-Queens University Press)). However, my argument in this article still runs even if people read Mill as withdrawing from socialism towards the end of his life (e.g. in Chapters on Socialism), so long as people accept he did have some interest in, and a view of a legitimate form of, socialism. For more on not reading Chapters as a withdrawal from socialism, see Stafford 1998.
} 


\section{A Brief Over-View of Mill's Socialism.}

Mill's socialism is a combination of commitment to core principles (utility, security, progress, liberty, equality, fraternity) and institutions. He considers socialism through both a social scientific and a normative lens, and in terms of what reforms we can feasibly institute now, and more 'ideal' critiques of capitalism and possibilities for future human relationships (see McCabe 2019a). He offers reasons for reform rooted in efficiency and expediency: for instance, that people are motivated to work harder when their interests are directly associated with the success of the firm for which they work - this is very little in wage-labor; more under profit-sharing schemes; and most under cooperation (Mill 1965, 204-205 and 769-794). He also offers reasons based more clearly in normative concerns, for instance about justice (Mill 1965, 199-214); the quality and nature of our relationships with other humans (Mill 1967a, 379-82); and the orientation of our interests towards the common good (Mill 1969a, 340-341; Mill, 1981, 239-241). Although not as critical of contemporary capitalism as many of his socialist contemporaries, Mill did offer some scathing attacks, and saw socialism as morally superior to, and also as having several more instrumental advantages over capitalism (though also some disadvantages, particularly regarding innovation and securing good management) (see McCabe 2015 and 2019a; Riley, 1996).

Although much inspired by the Saint-Simonians in the 1830s, and acknowledging a significant impact by them on his ideas of history, historical change, and the nature of the 'laws' of production and distribution (Mill 1981, 169-75 and 257), and despite defending Etienne Cabet in the press (Mill 1986, 1144-66; 1962a, 482; 1962b, 495; 1962c, 688), he was never in favor of state-scale socialism (Mill 1965 199-214 and 1967b, 748-49). Instead, he favored voluntarist associations, usually founded by a small number of people, and which, though they had the capacity to grow to be large-scale concerns would never comprise a whole state, or whole industry (Mill 1965, 199-214 and 775-794). These might be self-sufficient (as in the ideas of Owen or, as Mill preferred, Fourier), but more immediately they would be likely to take the form of producer or consumer cooperatives, which Mill calls 'associations of the laborers among themselves' (Mill 1965, 775-94). (For a discussion of the Fourierist links to the word 'association', see McCabe 2018.)

Mill described extant examples of such 'associations' at length in Principles of Political Economy, and sketches a vision of the economy transformed through cooperation whereby capital has been socialized to such an extent that even individual owners of capital have been brought to invest in cooperatives in return for an annuity (Mill 1965, 793-94). Alongside producer cooperation, he also mentions a role for the state - perhaps owning land ${ }^{3}$, protecting natural 'wilderness', and providing a series of goods and services including utilities, public parks, railway lines, funding for research, infrastructure for public health, street lighting, educational establishments, lighthouses and an atleast-minimal social safety net (Mill 1965 968-70 and 360). All of this is in combination with strict limitations on inheritance (only a 'moderate independence' for any one individual) (Mill 1965, 222-

\footnotetext{
${ }^{3}$ Mill denies that any legitimate argument which justifies holding private property can justify holding private property in land (Mill 1965, 227). In Principles he lists a variety of potentially just institutions for land-owning, recognizing that 'the use of land in agriculture must...for the time being, be of necessity exclusive; the same person who has ploughed and sown must be permitted to reap' (ibid.). These include occupying land for only one season; periodically redividing land ownership as the population increased; or the State acting as 'universal landlord, and the cultivators tenants under it' (ibid.). In later life, Mill was very involved in questions of Land Tenure Reform, chairing the Land Tenure Reform Association. Here, he was concerned with expediency more than ideal theory or historical practice, and resisted efforts to call for nationalization of land (Mill 1972; Mill 1967c; Claeys 2013, 159). He was concerned both with the injustice (or at least inexpediency) of nationalization plans which did not involve compensation for land-owners (and thought radical limits on inheritance could achieve the same outcomes, if slightly more slowly, at least more expediently), and with whether state agencies were yet capable of administering land in an efficient and uncorrupt way (Mill 1972). This is not to say, however, that he would not have favored state ownership of land which was achieved in and expedient fashion, and well-administered; certainly he does not rule it out on the grounds of justice in Principles.
} 
25 and 887-89) when there is still any private capital to be inherited (and as a key process for transition).

Producer cooperatives would transform industrial relations and practices. There would be no more class antagonism or oppression, because there would no longer be 'classes'. Everyone would be both laborer and "owner", allowing workers to be meaningfully independent and free (see also Baum 1998, 1999, 2000 and 2007). This would allow people to meaningfully interact as equals (if - and only if - 'both sexes participate equally in the rights and in the government of the association' (Mill 1965, 793-94), a very short caveat which involves a veritable revolution in social, economic and political relationships between the sexes; people's idea of gender and gender-norms; and education of both sexes). Producer cooperatives would provide the foundational education for, and institutions encapsulating, proper democratic, independent, and equal interactions, expanding Mill's concept of liberty into the economic sphere, and by combining cooperation and independence, lead to the realization of meaningful harmony of interests without compromising on individuality.

Consumer cooperatives would cut out middle-men and small shop-keepers who were 'mere distributors' taking an 'enormous portion of the produce of industry' (Mill 1965, 204 and 791). They would also radically change relations between producers and consumers (even in a 'marketstyle' economy), because producer cooperatives are responsive to the demands of consumer coops, and - at least where those are close as, for instance, they involve the same workers - then it is much easier to see that 'producers' and 'consumers' are the same people, a point Mill is keen to emphasize in his defenses of competition (Mill 1965, 794-96).

Of course, all this is very thin on actual detail - for Mill, this was a deliberate strategy. Although he did not dismiss as 'writing recipes for the cookshops of the future' (Marx 1887, 17) the kind of detailed blueprint designing so beloved by many contemporary socialists (instead abhorring the Marxists' apparent delighting in having no plan at all for after 'the Revolution' - Mill 1967b, 74849), he thought detailed institutional design could safely be left to the people of the future, who would have learned from the intervening years' of experiments and trial-and-error what actually worked (Mill 1965, xciii). But even saying this, it seems that - at least initially - Mill did not see 'socialism' as looking (for want of a better word) all that different to contemporary capitalism: there would still be firms, interacting with each other and exchanging goods and services which would be 'bought' by consumers; people would continue to live in towns, cities and villages (rather than being re-distributed across the landscape into evenly-sized intentional communities) and probably also in individual houses or flats (and perhaps also in nuclear families, though see the very brief engagement with less traditional family-structures in Mill 1984, 47).

It would, however, be a world transformed, however similar it appeared to be - and we ought to be cautious in assuming some similarities. For instance, though Mill would think it an improvement on his contemporary society if all large High Street retailers were profit-sharing 'partnerships' like Waitrose and John Lewis rather than exploitative private employers like Amazon or Sports Direct, we should be wary of assuming there would - in his ideal view - be anything like a modern-day High Street of competing stores seeking to maximize profits based on the models of a private consumer purchasing goods and 'shopping around' for preferred items, and producers seeking to 'buy, or make, cheap, and sell dear'. For Mill's socialism is both predicated on the idea of profits falling to zero (this is what helps encourage private capitalists to exchange their private fortunes for annuities paid out by cooperatives ${ }^{5}$ ), and on the idea of consumer cooperation, whereby consumers only 'shop' in one store, whose goods are sourced with their direct input from what they deem to be the 'best' suppliers.

\footnotetext{
${ }^{4}$ For more on this see Baum 1998, 1999, 2007 and 2000.

${ }^{5}$ For more on this, see Persky 2016.
} 
Given the general view Mill sketches, then, it is not entirely surprising that his views have been linked to 'market socialism'. However, we should inquire carefully into whether this is a useful way of understanding Mill's work, or whether - in particular - it both serves to over-play the role of 'the market' in Mill's socialism, and to continue a narrative whereby Mill is not 'really' a socialist (because he continues to endorse core 'liberal' institutions and values like competitive markets), and thus his actually radical ideas can be 'safely' ignored.

\section{Mill and Market Socialism}

As sketched above, Mill's commitment to worker-cooperatives interacting in some sort of 'market' looks - at least at first glance - an obvious candidate to be considered a form of market socialism. Generally speaking, market socialism demands the social ownership of capital, production organized through competitive markets, democratization of workplaces, and income distributed in a democratically-justified way (which may, or may not, be directly linked to the performance of cooperatives in the market). ${ }^{6}$

From the brief sketch above, we can see that this echoes Mill's ideas - at least at first glance. Mill wants workers to be autonomous - that is, self-governing and independent and yet working collectively, and making communal decisions; he wants income to be determined by democratic decisions based on shared commitments to justice and (as I have argued elsewhere, following Turner 2019a and 2019b) relational egalitarianism; and he wants capital to be socialized in a mixture of cooperatives and state-ownership. The question I want to really engage with here is the question to which he endorses markets as a means of allocation of resources and organization of production. I am particularly interested in four things: prices; the nature of 'competition'; the rationale for retaining markets; and the extent to which there will be 'markets' for goods and services in Mill's ideal cooperative future.

Prices

In the earliest market socialist ideas of Oskar Lange (following the analysis of Enrico Barone), prices are set by a Central Planning Board, and 'socialist' firms produce as much as they choose of any particular output, with management ensuring the marginal cost of production on each unit is the same as the 'price' set by the board (Bergson 1967, 656; Roosevelt 1969, 3; Barone, 2012). Consumers are faced with similar choices to modern consumers regarding how to spend their household income, and managers with a similar rationale to contemporary producers, except they cannot seek to undersell their competitors as a means of increasing their market share. The Planning Board, via trial and error, tries to set the price such that supply meets demand (ibid.). Bergson also suggests there might be two prices - one for producers and one for consumers - if, for instance, Planners wanted to use economic incentives to affect consumer behavior (in much the same way as current politicians do by taxing alcohol, tobacco, or sugar) (ibid., 657). As Barone notes, in a collectivist economy the word 'price' might not be used, but the Ministry of Production must set 'equivalencies' between certain goods, which perform the same function as prices (and are thus sometimes called 'shadow prices') (Barone, 2012, 93; Bradley and Mosca, 26-31).

Mill does not engage with the question of price-setting under socialism, but it seems unlikely he would support an institution such as a Central Planning Board or 'Ministry of Production'. For one, this is precisely because of the political manipulation they might impose upon pricing, which - at least when motivated by paternalist reasons - Mill views as illegitimate (Mill 1977, 298). For another, he is in general opposed to government interference in the economy especially where it is likely to be less efficient than non-interference, which seems likely in this case (Mill 1965, 944971). Moreover, although Mill wanted to see a collectivization of capital, this was not a centralized collectivization (meaning there would be no 'Ministry' tasked with solving the problems Barone -

\footnotetext{
${ }^{6}$ See, for instance, Arneson 1987; Bergson 1967; Shleifer and Vishny 1994; Ghosh 1995; Miller 1977 and 1989; Keren, 1993; Roosevelt 1969; Yunker 1974, 1975, 1986, 1988 and 2001.
} 
for instance - explicates (Barone 2012, 92)). That is, although Mill did think governments ought to be tasked with the general welfare, he did not think any government department ought to be made responsible, through management of a collectivized economy, for ensuring that individual and collective resources are combined to produce maximum welfare (though some of the same challenges might face a socialist government for Mill if - for instance - land had eventually been nationalized, and where there was to be some national, and even local, organization of industries which tend to monopoly).

Mill's own theory of exchange value relies on a relationship between utility $(\mathrm{U})$ and difficulty of attainment (D) (Mill 1965, 462-470), in which supply - eventually - balances with effective demand (Mill 1965, 464-71). Although equation of supply and demand will set the market price, this must first exceed the costs of production, or nothing will be produced at all (ibid., 471). There needs also to be some profit, else capitalists will not lend their capital to the productive enterprise (ibid.) Adding these two together provides what Mill calls the 'Necessary Value', 'the minimum with which the producers will be content' (ibid). And in a 'free and active' market, this 'necessary value' is the maximum price which any producer can expect (ibid., 471-72). This is because supply and demand works for profits, too - where there seem to be above-average profits to be made, capital investment will rush in, and soon pull the profits back down (ibid., 472). Thus, Mill says, investors should expect a similar return on their investments in all 'different occupations' (ibid.). Because increase in supply is never immediately responsive to prices; and because demand is also not always response to prices (Mill was getting at more modern ideas regarding elastic and inelastic demand without using that terminology ${ }^{7}$ ) Mill concludes 'demand and supply always rush to an equilibrium, but the condition of stable equilibrium is when things exchange for each other according to their cost of production' (ibid., 475-76).

Although Mill talks about Value, Price, Supply and Demand etc. in Book III of Principles, and about socialism in Books II and IV, and thus never engages directly with the question of supply, demand and price under his preferred socialist institutions, we are warranted in reading Mill as eschewing price-setting boards, and favoring prices set 'naturally' by cost of production. I note that - in Barone and Lange, at least - the 'price setting board' may have to work out the price it sets via a series of trials and errors, and cannot - consistent with maximizing welfare and/or efficiency - set these prices a priori. But I think we are warranted in reading Mill was eschewing the centralization of price (or 'exchange value') at all, and leaving it to the market (and individual choices) as part of his wider avoidance of centralization, and view that central organization and planning of a whole economy was 'obviously chimerical' (Mill 1967b, 748 - see also preceding discussion (737-48) for Mill's wider concerns regarding the feasibility even of small-scale centralized "communist" communities).

That Mill eschewed central price setting is supported by considering the kind of socialist institutions Mill had in mind, and his support for 'divi' as invented by the Rochdale Pioneers (Mill 1965, 768-792). Producer cooperatives have to cover their costs of production (obviously), and although not paying wages, they need to cover the costs of labor by ensuring sufficient 'profit' to divide among members. (This, of course, reflects a more subjective view as to what their labor is worth than in capitalist markets, where workers, in the main, have to take the wage offered, even if they consider it not only too little to really cover their basic needs, but also 'insulting'.) Producer cooperatives may also need to cover the return on investment expected by investors. In the early days of a transition to cooperation, these are likely (for Mill) to be private investors, but over time they may become other cooperatives, pensions or other mutual benefit funds etc.

On the other hand, a multiplicity of cooperatives - and a generally laisser-faire governmental approach - should ensure competition between producer-cooperatives which prevents them from

\footnotetext{
7 Bladon (1965, liii) notes, '[t]he essential notion of elasticity of demand, present in Adam Smith, was clarified in Mill and only waited to be christened by Marshall'.
} 
charging prices much above the 'Necessary Value'. This is one of the things Mill urges as an advantage to consumers of competition, reminding socialists that not all competition is necessarily bad (Mill 1965, 794-96). And consumer cooperatives are not profit-seeking enterprises. It is in their interests, certainly, to 'buy cheap', but not in their interests to 'sell dear', because the dividend model means that any 'surplus' at the end of a set period (i.e. quarterly, or annually) which has been accrued over-and-above costs of buying goods, overheads (including payments to those who work in the shop), and any other long-standing commitments the consumer cooperative might make (e.g. to an insurance fund/pension, or to an educational fund, as many consumer-coops did in the nineteenth century) is distributed back to consumers in the proportion that they spent money in the coop. Thus, although not immediately when at the till, over time members of a consumer-coop pay cost-price - not exactly the cost-price faced by the producer, because the consumer-coops' own overheads have to be added in, but the 'Necessary Value' viewed from a retailer's perspective. (And though they might have an incentive to do so, consumer-coops cannot buy at a cost below the cost of production for the producer-cooperative, because no producer-coop would sell at that price; and no consumer-cooperative would have enough market power to force them to - even if all of these considerations did not rely on a very difference idea of motivation to that endorsed by Mill, to which I will turn later.)

Mill reminds workers (producers) that they are also consumers: in a competitive cooperative market, dividends from labor might be lower, but so are prices in shops. I read Mill as retaining this view under socialism, and being unlikely to support price-setting mechanisms. ${ }^{8}$ I note that more modern market socialist ideas often dispense with this part of Lange's plan (e.g. Yunker 1974, 197-98); thus, because Mill is unlikely to have supported centrally-set prices, this does not prevent him from being a market socialist. However, this discussion also highlights perhaps a more important element. Mill supports competition because it leads to low prices (and thus an increase in the value of real wages), and thus to a general increase in utility. (That is, when prices go down but wages stay the same (or increase), people can either buy more for their money, or choose to work less and still buy what they used to.) He is not concerned that high prices represent an inefficient use of resources (even his concern with monopolies is that the profits are unjust, not particularly that they are preventing resources from being better-invested elsewhere). In part, this is because Mill is not interested in maximizing production. He does not equate production with welfare. He is instead interested in ensuring we produce enough (of all the things people both need and enjoy), within institutions (such as price) which mean the most people possible can enjoy them, and that what we have is distributed fairly among everyone. He is very much opposed to production for production's sake, or to the mere increase in things produced being a good test for a society's success (Mill 1965, 753-57).

Indeed, Mill is interested in a qualitatively different inter-relationship between people. This strongly affects motivation, and thus provides a different view of price. Above, I noted that Mill's notion of 'price' is that it will correspond - over time, despite some fluctuations - to 'Necessary Value': that is, to the costs of its production plus whatever is necessary to pay to investors for the use of their capital. Under cooperation, this 'Necessary Value' represents something slightly different. As before, it has to cover the costs of raw materials and energy, as well as labor-costs (though not wages), and there may or may not be investment costs. As mentioned above, in cooperatives people work for a share of the 'surplus', not for wages: so there needs to be a surplus which adequately represents what people feel their labor is worth (and are therefore willing to work for). This represents both the cost of meeting their own basic needs (and those of their dependents,

\footnotetext{
${ }^{8}$ Bergson (1967), following Ward, argues that even a cooperative model would be inefficient. The cases he has in mind are not precisely akin to Mill's (where cooperatives do not pay a tax to the State for the use of communal property - the property is collectively owned by the members of the cooperative, not by every member of society with the State acting as agent), but there might still be problems Mill did not foresee with his cooperative socialist plans.
} 
if they have any), but also other 'costs' including their self-respect, and things beyond their basic needs that they want to enjoy. Of course, these last two may prove more elastic than the first, particularly in times of economic hardship (even under global socialism, workers may not be immune to economic bad times caused by bad weather, poor harvests, global pandemics etc.). To take 'investment' - on the one hand this is covered by labor-costs, because the workers themselves own the capital they have pooled to form the cooperative. On the other, they might have borrowed money (or, in some days of Mill's perceived transition to socialism, be paying interest to private capitalists, and/or still be paying out annuities as a return for having been given the capital), so these costs would need meeting. But there would be no further incentives to increase price - and there are several incentives to keep it as low as possible, which are not rooted in a desire to maximize profits.

Mill favors socialism because not only does it set people free in their workplaces, giving them democratic and autonomous control of one of the most important elements of their lives; and not only does it encourage and facilitate much greater equality (and just distribution of resources); but because it makes people view each other in a better way. Under socialism, we are motivated towards the common good, and - as part of that- we are motivated towards everyone's good. Socialism puts an end to the 'irritating sense of contrariety of interest' (Mill 1982, 487), and under its institutions we would be able to cultivate 'the feeling of unity with our fellow creatures' to such an extent that it will be as deeply-rooted 'in our character, and to our own consciousness as completely a part of our nature, as the horror of crime is in an ordinarily well-brought up young person' today (Mill 1969b, 227). He says:

every person who lives by any useful work, should be habituated to regard himself not as an individual working for his private benefit, but as a public functionary, and his wages, of whatever sort, not as the remuneration or purchase-money of his labor, which should be given freely, but as the provision made by society to enable him to carry it on, and to replace the materials and products which have been consumed in the process ... [1]n modern industry, every one in fact works much more for others than for himself, since his productions are to be consumed by others, and it is only necessary that his thoughts and imagination should adapt themselves to the real state of the fact. The practical problem, however, is not quite so simple, for a strong sense that he is working for others may lead to nothing better than feeling himself necessary to them, and instead of freely giving his commodity, may only encourage him to put a high price upon it ... What [is] really mean[t] is that we should regard working for the benefit of others as a good in itself; that we should desire it for its own sake, and not for the sake of remuneration, which cannot justly be claimed for doing what we like: that the proper return for a service to society is the gratitude of society: and that the moral claim of any one in regard to the provision for his personal wants, is not a question of quid pro quo in respect to his cooperation, but of how much the circumstances of society permit to be assigned to him, consistently with the just claims of others ... The rough method of settling the labourer's share of the produce, the competition of the market, may represent a practical necessity, but certainly not a moral ideal. Its defence is, that civilization has not hitherto been equal to organizing anything better than this first rude approach to an equitable distribution (Mill 1969a, 340-41).

If workers in producer-cooperatives thought like this, they could not demand much on top of the costs of production (though there would also be no false sense of their own lack of worth), and they would have no incentive to charge consumer-cooperatives more than the 'Necessary Value' of their goods. Moreover, consumer-cooperatives would not try to pay less than this 'Necessary Value' (they would not want to buy things made under exploitative working conditions, for instance, where workers are not (even) paid enough to property cover the costs of their own labor). 
This is especially the case (and perhaps also more likely) when we consider that Mill seems to see the relationship between producer- and consumer-coops as being quite intimate. That is, members of a consumer-cooperative are not only almost certain to work for some sort of producer-coop, but quite likely one which supplies at least some goods or services to the consumer-cooperative of which they are a member. (Indeed, consumer-cooperatives were often set up with an eye to helping workers save enough capital to start a producer-cooperative, and Mill records the diversification of the Rochdale Pioneers from small shop selling necessities to investing in a fellow cooperative Corn Mill, which would exclusively supply their store (Mill 1965, 769-770).)

We have moved a long way, it may seem, from price, but it is important to understand how much Mill thinks will change under socialism. This affects how he thinks prices will be set, but also affects much more including - as I will consider further below - the extent to which his is a form of 'market' socialism at all (even where he conceives of exchange between cooperatives).

\section{The Nature of Competition}

This brings me nicely to the question of the nature of 'competition'. As noted, Mill was not entirely opposed to competition, and he thought socialists who were betrayed a misunderstanding of some basic tenets of economics (such as: where competition is not, monopoly is) (Mill 1965, 794-96). But as also noted, he did not approve of 'contrariety of interests', or of 'the trampling, crushing, elbowing, and treading on each other's eels, which form the existing type of social life' (Mill 1965, 754). Indeed, in considering 'competition' he notes that much may be meant by the term - not all of which, evidently, he supports - and that 'a contest, who can do most for the common good, is not the kind of competition which Socialists repudiate' (Mill 1965, 205).

Similarly, in describing the possible cooperative 'utopia' which might emerge in the not-too-distant future, Mill says:

It is scarcely possible to rate too highly this material benefit, which is yet nothing compared with the moral revolution in society that would accompany it: the healing of the standing feud in between capital and labor; the transformation of human life from a conflict of classes struggling for opposite interests, to a friendly rivalry in the pursuit of a good common to all; the elevation of the dignity of labor; a new sense of security and independence in the laboring class; and the conversion of each human being's daily occupation into a school of the social sympathies and the practical intelligence (Mill 1965, 792).

I have written at length (McCabe 2018) on the links between this idea of 'friendly rivalry' and the Fourierist one of 'emulation' arising from the 'cabalistic passion' (Fourier 1901, 57-59, 158 and 164-5; Considerant 1845, 35-7; Considerant 1837, 378). This is a kind of 'competition', but one which brings people together and which drives people to excel. An obvious example is that of rival sports teams: supporters feel a very strong connection to each other and their team, and the competition between teams drives individual athletes (and, in a different way, supporters) to do the best they possibly can.

Of course, rival sports teams are often famously un-"friendly" towards 'rival' fans, and there is a concern that even 'friendly-rivalry' (in a Fourierist sense) would lead to attempts at price-cutting, driving other cooperatives out of the market etc., which characterize contemporary 'elbowing, crushing and trampling'. But this 'friendly rivalry' would also be tempered by the underlying desire for unity of interests just as we occasionally see even in contemporary sports, with athletes helping injured colleagues instead of pipping them to the finish, or supporters aiding the fight to keep rival teams from going out of business. The ideal 'friendly rivalry', then, might encapsulate what is supposed to be the spirit of the Olympics - peace and unity (rather than national competition) whilst cheering on all those who endeavor to reach new heights of sporting prowess. 
Applied to competitive markets, then, 'friendly rivalry' would see firms keen to 'emulate' the success of others by adopting their best-practices (which might counter some of Mill's concerns about stagnation in innovation under 'communism' - in themselves, not necessarily entirely applicable to cooperative socialism) (Mill 1967b, 739-42). No one would want to see other cooperatives fold, and would not try to expand to take their market share, though there might be some 'friendly' competition for business (though even this would need to be balanced against concerns about contrariety of interests - doesn't taking a significant share of another cooperative's business amount to 'harm' of the kind a normally 'well-brought-up young person' would eschew under socialism? Consider, after all, that inflicting similar economic harm through some other means would nowadays be viewed with deep-rooted horror, and there would be even more consideration of what was at stake (independence and liberty, as well as economic well-being) in a socialist future.)

I mention all of this because once we think firms would be trading basically at cost-price, and once we think that 'competition' would be 'friendly-rivalry', I consider there to be a significant impact on what we are calling a 'market' (and thus 'market socialism'). This leads me to my final two points - Mill's rationale for markets, and the extent to which there will be 'markets' under his preferred form of socialism.

\section{Mill's Rationale for Retaining Markets}

Mill nowhere defends the idea of 'markets' under socialism, so there is no direct textual evidence to explore. Instead, he directly defends 'competition' and - as noted above - what this 'competition' will consist in, how it will be motivated, and therefore what it will be like and result in, shift with the corresponding changes in human nature Mill perceives will also come about through socialist institutions. This said, Mill's justification for competition relies on considerations regarding the cheapness and quality of consumer goods, and retaining efficiency and innovation in production (Mill 1965, 794-96). His rationale for why it is generally better to let people do things for themselves (i.e. laisser-faire) include (regarding 'authoritative' interferences - i.e. those that people cannot avoid): a general concern for liberty (as encapsulated in the harm principle), which does not apply to government interferences which, rather than inhibit liberty, enable it; a general concern that increasing government power increases the risk of bad consequences were that power ever to be abused combined with a general concern that people think they can and indeed should use state power to achieve their ends (not necessarily with the consent of dissenters); that government action is, in general, worse than when people do things for themselves, as they are most nearly connected to the issue; and that it is important that people cultivate collective habits of working together for their own good, rather than passively relying on the state (Mill 1965, 83644).

None of these directly correspond with the general defenses of including 'markets' in socialism. These often concern efficiency of production understood as maximization of production - but as noted above, this was not something of which Mill entirely approved. (He would not take increasing GDP to be a good proxy for increasing social success.) He does not overtly say that markets make production more closely match consumption, or meet consumer needs - though the view that government action (and operation of industry) is, in general, less efficient than people doing things for themselves, and his view that production being organized centrally is 'obviously chimerical' might cover this kind of concern (Mill 1967b, 748). (Though it is worth noting that when Mill compared corporations to public production, he found corporations wanting. (Mill, 1965, 938.)) Similarly, Mill's view that profits (in the long run) inevitably tend to zero; and that it would only be when people were really capable of being motivated to work for more than the maximization of their own self-interest that cooperation would really work and really bring about a 
moral transformation of society ${ }^{9}$ mean Mill was not concerned with 'profit-maximization' under socialism, and did not endorse markets as a means of maximizing profits (and therefore efficiency of production etc.) under socialism.

Moreover, some of Mill's concern about the cheapness of goods applies only to capitalist, or transitional, markets - once everyone adopts the 'dividend' model, the - as it were - 'face value' of goods in consumer-cooperatives becomes less important, as 'dividend' ensures consumers 'pay' something much closer to cost-price - indeed, as noted above, pay the minimum the consumercooperative can afford to sell goods for, incorporating into that 'price' other expenditure that members of democratic consumer-cooperatives also consent to (e.g. money for an education fund, for mutual insurance, pensions etc.). This said, exchange still works to keep producer-cooperatives 'honest' regarding price (i.e. efficiency of their productive processes) and quality of their goods: if consumer-cooperatives are not happy with the quality of goods they source from producercooperatives, were will be other producer-cooperatives from whom they can source goods instead.

'Markets', then, for Mill are worth retaining in a socialist future because independent cooperatives organizing production for themselves is more likely to be feasible and lead to high-quality, lowcost goods than a state-planned alternative. But the motivations under which people will act in these 'markets' are very different to many of those assumed by defenses of 'markets' in 'market socialism'. That is, people working in a socialist future, for Mill, will be motivated not by selfinterest but by considerations of the common good. The 'threat' that consumer-cooperatives might take their business elsewhere is not needed to keep producer-cooperatives from adulterating or making poor-quality goods (both professional pride, and an emulative desire to do others' good will motivate a desire to produce high-quality goods); nor is it necessarily needed in order for producer-cooperatives to seek to keep their costs low (both because of a desire to do others good, rather than exploit them, and also because producers will recognize that they, too, are consumers - even, in some cases, of their own goods - and that a general will towards efficient production is beneficial for everyone).

Indeed, although Mill does provide positive arguments for cooperation, many of his defenses of cooperatives (and, beyond that, 'market socialism') are about the freedom cooperatives give to workers (see also Baum 1998, 1999, 2007 and 2000), and the increased equality (of income, but also for women) and justice they can attain (e.g. Mill, 1965, 793-4). That is, they are not economic rationales at all, but normative ones.

Thus, Mill's rationale for markets is different to most defenses of 'markets', in both capitalist and market-socialist theory. True, for Mill, some of the same economic or psychological arguments might apply while we are in a transitionary period between capitalism and socialism - but it is also noteworthy that he extols cooperators not to fall prey to more 'capitalist' motivations (e.g. by employing workers for wages, rather than offering them full membership) (Mill 1965, 792; Mill 1988), and in more general terms looks forward to a more 'organic' age of society where these individualistic and selfish tendencies will have been overcome (e.g. Mill, 1981, 239). Indeed, he deliberately links them to the current level of economic, social and political progress and a specific distribution of economic resources, all of which will be transcended by socialism (Mill 1965, 754). It would be odd, then, if he retained markets in anything other than a transitional age for reasons which would allow negative normative elements of capitalism to continue, and prevent the moral gains of socialism from being made.

\footnotetext{
9 Profit-sharing, on Mill's view, is a good way of maximising people's motivation to work for their own interests (both capitalists, and workers): but cooperation involves an ability to work for a more collective good, even if it is - in general - true that the more one works individually in a cooperative, the better one will do (because the better the concern will do), though this is also affected by the principle of justice on which distribution in the cooperative is founded (from piece-work - which does relate to self-interest - to 'from each according to their capacities, to each according to their needs', which does not).
} 


\section{Will there be 'markets' in Mill's socialism?}

This brings me to my final point - a wider question of whether there will be 'markets' in Mill's preferred socialism. My discussion here is a reconstruction of Mill's view, and thus necessarily somewhat speculative, as this is not something Mill addresses directly.

Evidently, there will not be 'labor markets' as we now understand them, and as were criticized by contemporary socialists. That is, people will not be hired for wages; workers will not compete among themselves for jobs (including undercutting each other in the job market) because everyone's subsistence will be assured (via a welfare safety-net), population rates will be kept under control (not over-stocking the labor markets), and people will be able to set up their own cooperative endeavors if they are - for some reason - unable to attain membership in existing cooperatives. Cooperatives will not compete with each other for workers by offering monetary incentives (though potentially they might offer people other incentives, connected to managerial opportunities, opportunities to experiment with new technologies, or just a chance to change jobs). (This said, there might be some competition in monetary terms: all cooperatives democratically decide how to split their surplus - they might offer increased dividends to people with particular talents etc. they want to attract - similarly, they might attract people on moral grounds, who prefer their distributive principles.) In terms of opportunities for employment, there will no longer be 'elbowing, crushing and trampling', though there will be movement between jobs and cooperatives (at least potentially). People might still be 'poached' by particular cooperatives (or leave, and set up their own), but even where there might be competition between workers for scarce opportunities (only one person at a time, after all, can conduct a Philharmonic orchestra; and very few will ever go into space), this will not be the 'cut-throat' kind of competition in a labor market with which Mill was familiar.

This much, however, is common to most market socialist approaches. In Mill's view, there is certainly exchange between producer- and consumer-cooperatives, but I want to interrogate further whether there is a 'market' for goods and services.

Mill disliked 'middle-men' distributors, seeing them as inefficient and adding to costs for consumers. In a socialist future, then, we should imagine very direct relations between producerand consumer-cooperatives. Mill may have envisaged consumer-cooperatives acting more like wholesalers than small 'corner-shops' (as the Rochdale Pioneers premises in Toad Lane originally started out life as), either with small groups of consumers coming together to source goods from cooperative wholesalers (and acting as a new kind of 'middle-men', not seeking to make a profit from their endeavors), or with people perhaps travelling further to source goods (e.g. into 'town' rather than on the corner of their street) from large wholesale warehouses. In Mill's time, when storing goods at home was harder (without fridges or freezers), and when people's pay meant they had little opportunity to buy in bulk, or even meet more than their weekly needs, this might have seemed harder, but in the modern era of supermarkets, it is easier to imagine. Certainly, I think we can say consumer-cooperatives would not 'market' their wares as modern shops do - that is, they are not shops trying to compete with each other for a pool of customers (and their money). Instead, consumer-cooperatives know their 'consumers' because they are their members, and their buying strategies are democratically directed by the membership, and responsive to their needs. Consumer-cooperatives are not trying to make profits for owners/shareholders (because their 'owners' are their customers), and though customer-owners 'benefit' from profits through the 'dividend model', of course this is not an incentive to increase the difference between cost-price and sale-price, because those same owner-customers pay the sale-price in the first place. (Nor is it an incentive to increase membership.) So, under Millian socialism there would be very few retail outlets; people would probably only belong to one consumer-cooperative (covering a specific area, perhaps, or perhaps everyone they work with); and these retail outlets would not be in competition 
with each other for members (though, of course, people might change what consumercooperatives they were members of, depending on personal choice).

These consumer-cooperatives would all be supplied by producer-cooperatives. (Not all producercooperatives would supply consumer-goods, but many would.) Here there might well be competition between producer-cooperatives for custom, because workers in producercooperatives do indeed benefit from increased sales (and a resulting increase in the surplus to be shared among all members - or, at least, they are likely to, depending on how that increase in sales was achieved). Here the idea of 'friendly-rivalry' and 'emulation' comes into play, as producercooperatives try to out-do each other in their success (presumably measured in size of membership, how many consumer-coops they supplied, their reputation as somewhere that provided high-quality goods for reasonable prices etc.). There is, then, something like a 'profitmotive' for producer-cooperatives. But even this is tempered by other concerns (environmental, social, normative), and producer- and consumer-cooperatives presumably do not merely interact via a 'cash...nexus' (which Mill deplores - 1967a, 379). That is, consumer-cooperatives might be responsive to a great deal more than price (and there will be a much more direct relationship - or recognition of the relationship - between producer and consumer, who may be the same person). Moreover, on Mill's view of markets and rates of profit, all producer-cooperatives will be selling at the Necessary Value. This might change from cooperative to cooperative, but there would presumably not be much leeway (and, moreover, the 'necessary value' cannot be depressed - as under capitalism - by paying lower-than-subsistence wages). Where all firms are producing goods of a similar quality for a similar price, 'competition' and 'the market' look rather different to how they appear under capitalism.

Something similar could be said for producer-cooperatives selling goods not directly to consumercooperatives, but to other producer-cooperatives (e.g. people who process raw materials; people who sell agricultural products to farmers, and/or to restaurateurs; people who make parts for machinery etc.). Choice of suppliers helps guarantee quality goods which are being sold at (close to) 'necessary value', and the ability to expand sales if a competitor falls in quality or rises in price of course leads to certain kinds of competition between firms (which Mill might think are a part of 'a contest, who can do most for the common good' which - he argues - 'Socialists [do not] repudiate' (Mill 1965, 205)). But, as already noted, this competition is tempered by being 'friendly', and through a general desire for unity of interests with one's fellow-citizens.

Lastly, given Mill's endorsement of Blanc's ideal of 'from each according to his capacities; to each according to his needs', and this deep-rooted concern with each other's' happiness that Mill wishes to see established in future society (combined, also, with his criticisms of certain kinds of 'unproductive labor' on which time, energy and resources are currently squandered), Mill may foresee a socialist future in which production is much more responsive to need than in the contemporary world (where production is responsive to profit, and may leave many needs un-met, whilst overfulfilling many others). Of course, there may still be the problem - mentioned above - of demand needing to be effectual, i.e. not merely a wish for something, but the ability (usually monetary) to attain that wish. But in a society much more responsive to need, perhaps fewer people would have at least basic needs and no effectual demand for goods and services which met them (e.g. through a system of welfare payments). And democratically-controlled producer-cooperatives could choose to be responsive to needs, even where these were not backed by effectual demand, at least to some extent (i.e. not so much they went entirely out of business), as a decision they made regarding what surpluses they would make, and how they would distribute them. Mill might see a decentralized economy as much more likely to be sensitive and responsive to needs - and better equipped to meet them efficiently - than central state institutions: but such a decentralized, needsbased, needs-responsive economy would not look much like a 'market'. 


\section{Conclusion.}

Mill certainly endorsed a decentralized economy where producer- and consumer-cooperatives exchanged goods and services among themselves for money. ${ }^{10}$ Some additional goods and services would be provided by the state, but Mill sees government provision as the exception not the rule, and that there will be relatively little interference in the economy. His vision of independent producer- and consumer-cooperatives interacting in this way - which he calls 'the nearest approach to social justice' and his 'utopia' - have been called a species of 'market socialism' in the past.

In this paper, I have interrogated the extent to which there will be 'markets' in Mill's socialism. Importantly, although Mill talks of interactions characterized by 'friendly rivalry', and explains that socialists ought not to eschew all competition (which secures high quality goods and reasonable prices for consumers), how cooperatives interact, how individual workers are motivated, and the end-goal of society in general is not only different to contemporary capitalism, but also at odds with many strands of market socialist thought.

In particular, 'market socialism' has been criticized for not being really 'socialist', given its willingness to harness individualist, and selfish, interests; willingness to incorporate into socialist production a 'profit-motive'; and general embrace of competition between workers which seems at odds with the fraternal, communitarian, 'social' heart of 'socialism' (as well as potentially contriving important egalitarian elements) (see, for example, Cohen 2009, 66-72, and 1995, 25564). But Mill's socialism is not vulnerable to such criticisms, because he deliberately does not want to incorporate these capitalistic rationales into future socialism, but somehow marry decentralized, democratic production with meeting needs; egalitarianism; individuality; and 'sociability', or the inability to be comfortable with 'contrariety of interests' between you and your fellow-citizens. Given this, the label 'market socialist' might not be the best for Mill. But it also means that there is much to explore in his writing for anyone who favors democratic, decentralized production without wishing to have to compromise regarding other key normative elements of socialism, most obviously its 'social' element.

Word Count: 9682

\section{Bibliography}

ARneSOn, RiCHARD J., Ethics, 'Meaningful Work and Market Socialism' (1987) 97/3: 517-545.

BAIN, AlEXANDER, John Stuart Mill: A Criticism (London: Longmans, Green and Co., 1882).

BARONe, Enrico, Giornale deglu Economisti e Annali di Economia, Nuova Serie Final Issue: Classics from the "Giornale Degli Economisti" in English Translation, 'The Ministry of Production in the Collectivist State', (2012) 71(Anno 125)/No.2/3: 75-11.

Baum, Bruce, J.S. Mill's Political Thought: A Bicentennial Reassessment (Cambridge: Cambridge University Press) edited by Nadia Urbinati and Alex Zakaras, 'J.S. Mill and Liberal Socialism' (2007): 98-123.

Polity, 'J.S. Mill on Freedom and Power', (1998) 31/2: 187-216.

History of Political Thought, 'J.S. Mill's Conception of Economic Freedom', (1999) 20/3: 494-530.

Rereading Power and Freedom in J. S. Mill (Toronto: University of Toronto Press, 2000).

\footnotetext{
10 Minting money is one of the legitimate 'authoritative' interferences Mill accords to government, and it seems reasonable that he sees producer- and consumer-cooperatives as using money as a useful token of value for exchange.
} 
Bergon, ABRAM, Journal of Political Economy, 'Market Socialism Revisited', (1967) 75/5: 655-673.

Bladon, Vernon, Principles of Political Economy, edited by John Robson (Toronto: University of Toronto Press) 'Introduction' (1965), .xxiii-lxiii.

Bradley, Michael and Manuela Mosca, Universita di Lecce, Department of Economics, Mathematics and Statistics, 'Enrico Barone's "Ministry of Production": Content and Context', (2010) 144/51: 1-49.

CAPALDI, NichOlas, The Tocqueville Review, 'Mill and Socialism', (2012) 33/1: 125-144.

Claeys, Gregory, Mill and Paternalism (Cambridge: Cambridge University Press, 2013).

Journal of Politics, 'Justice, Independence, and Industrial Democracy: The

Development of John Stuart Mill's Views on Socialism', (1987) 49/1: 122-147.

Cohen, G.A., Why Not Socialism? (Princeton: Princeton University Press, 2009).

Self-Ownership, Freedom and Equality (Cambridge: Cambridge University Press, 1995).

COnsiderant, Victor, Destineé Sociale (Paris: Bureau de la Phalange, 1837).

CONSIDERANT, VICTOR, Exposition abrégée du système phalanstérien de Fourier (Paris: Librairie Sociétaire, 1845).

DunCan, Graeme, Marx and Mill (Cambridge: Cambridge University Press, 1973).

FOURIER, CHARLES, Selections from the Works of Fourier translated by Julia Franklin (London: S. Sonnenschein, 1901).

Flew, Anthony, Prophets of Freedom and Enterprise (London: Kogan Page for Aims of Industry) edited by Michael Ivans, 'J.S. Mill: Socialist or Libertarian?' (1975), 21-26.

Fredman, L.E and Gordon, B.L.J., Mill Newsletter, 'John Stuart Mill and Socialism' (1967) 3/1: 3-7.

GRAY, JOHN, Liberalism (Buckingham: Open University Press, 1995).

GHosh, Arun, Economic \& Political Weekly, 'Capitalism, Markets, Market Socialism and Democracy', (1995) 30/50: 3191-3194.

HAINDS, J.R, Journal of the History of Ideas, 'John Stuart Mill and the Saint-Simonians', (1946)7/1: $103-12$.

Hollander, Samuel, The Economics of John Stuart Mill, Volume 2: Political Economy (Oxford: Blackwell, 1985).

KurER, OsKar, The Economic Record, 'J.S. Mill and Utopian Socialism', (1992) 68/202: 222-32.

KEREN, MichaEL, Eastern Economic Journal, 'On the (Im) Possibility of Market Socialism', (1993) 19/3: 333-344.

Losman, Donald, L, American Journal of Economics and Sociology, 'J.S. Mill on Alternative Economic Systems', (1971), 30/1: 84-104.

MACPHERSOn, C.B., The Life and Times of Liberal Democracy (Oxford: Oxford University Press, 1977). McCabe, Helen, The Tocqueville Review, 'Mill and Socialism: A Reply to Capaldi', (2012) 30/1: 145164.

A New Social Question: Capitalism, Socialism and Utopia edited by Casey Harrison (Cambridge: Cambridge Scholars Publishing) 'John Stuart Mill's Analysis of Capitalism and the Road to Socialism', (2015), 8-22.

Global Intellectual History, John Stuart Mill and Fourierism: "Association”, "Friendly Rivalry" and Distributive Justice', (2018) 4/1, 35-61.

Utilitas, 'Navigating by the North Star: The Role of the "Ideal" in John Stuart Mill's View of "Utopian" Schemes and the Possibilities of Social Transformation', (2019a) 31/3: 291-309.

Utilitas, 'Mill's “Modern” Radicalism Re-Examined: Joseph Persky's The Political Economy of Progress' (2019b), 32/2: 147-164.

MARX, KARL Capital I (Moscow: Progress Publishers) 'Afterword to the $2^{\text {nd }}$ Edition' (1887): 12-22. MEDEARIS, John, American Journal of Political Science 'Labor, Democracy, Utility, and Mill's Critique of Private Property', (2005) 49/1: 135-149.

Mill, John STUART. Autobiography, Collected Works of John Stuart Mill I (Toronto. University of Toronto Press, 1981). 
Principles of Political Economy, CW II and III (Toronto: University of Toronto Press, 1965).

The Claims of Labour, Collected Works IV (Toronto: University of Toronto Press, 1967a.). Chapters on Socialism, Collected Works V (Toronto: University of Toronto Press, 1967b). Land Tenure Reform, Collected Works V (Toronto. University of Toronto Press, 1967c). Re-Organisation of the Reform Party, VI (Toronto, University of Toronto Press: 1982). Anguste Comte and Positivism, CWX (Toronto: University of Toronto Press, 1969a). Utilitarianism, $C W \mathrm{X}$ (Toronto: University of Toronto Press, 1969b).

Letter 1690, to John Stapleton, 25 October, 1871, XVII (Toronto, University of Toronto Press: 1972).

On Liberty, CW XVIII (Toronto, University of Toronto Press: 1977).

On Marriage, CW XXI (Toronto, University of Toronto Press: 1984).

'French News [64]', Newspaper Writing, XXIII (Toronto, University of Toronto Press: 1962a).

1962b).

'French News [66]' Newspaper Writings, XXIII (Toronto, University of Toronto Press:

'French News [90]' Newspaper Writings, XXIII (Toronto, University of Toronto Press: 1962c.).

'M. Cabet' (Letter to the Daily News, 30 October 1849), CWXXV (Toronto, University of Toronto Press, 1986).

Co-operation, CW XXVIII (Toronto, University of Toronto Press: 1988).

Miller, Dale E., Politics, Philosophy and Economics, 'Mill's "Socialism"”, (2003) 2/2: 213-38.

MiLler, DAVID. Market, State and Community: Theoretical Foundations of Market Socialism (Oxford: Clarendon Press, 1989).

Political Theory, 'Socialism and the Market' (1977) 5/4: 473-490.

PERSKy, JosePH, The Political Economy of Progress: John Stuart Mill and Modern Radicalism (Oxford, 2016).

Utilitas, 'Mill's Socialism Re-Examined', (2019): published online.

RAWLS, JoHn, Justice as Fairness: A Restatement (London: Harvard University Press, 2001).

A Theory of Justice (Oxford: Clarendon Press, 1972).

REEVES, RichARD, John Stuart Mill: Victorian Firebrand (London: Atlantic, 2007).

Riley, JONATHAN, Utilitas, 'J.S. Mill's Liberal Utilitarian Assessment of Capitalism versus Socialism', (1996) 8/1: 39-71.

Roosevelt, Frank, Journal of Economic Issues, 'Market Socialism: A Humane Economy?’ (1969) 3/4: 3-20.

Ryan, Alan, J.S. Mill's Political Thought: A Bicentennial Reassessment (Cambridge: Cambridge University Press) edited by Urbinati and Zakaras, 'Bureaucracy, Democracy, Liberty: Some Unanswered Questions in Mill's Politics' (2007).

Sarvasy, Wendy, The Western Political Quarterly, 'A Reconsideration of the Development and Structure of John Stuart Mill's Socialism’ (1985) 38/2, pp.312-333.

SCHAPIRO, SALWYN J., Journal of the History of Ideas, 'John Stuart Mill, Pioneer of Democratic Liberalism in England', (1943) 4/2: 127-160.

SCHLEIFER, ANDREW AND Vishny, ROBERT W., Journal of Economics Perspectives, 'The Politics of Market Socialism', (1994), 8/2: 165-176.

Schwartz, Pedro, The New Political Economy of J.S. Mill, translated George Weidenfeld and Nicholson Ltd. (London: London School of Economics, 1972).

STAFFORD, WiLliam, Journal of Political Ideologies, 'How Can a Paradigmatic Liberal Call Himself a Socialist? The Case of John Stuart Mill', (1998) 3/3: 325-45.

ThOMas, William, Mill (Oxford: Oxford University Press, 1985).

TURNER, PIERS NORRIS, The Routledge Handbook of Theories of Luck, edited by. Ian M. Church and Robert J. Hartman (Routledge), 'Luck and Distributive Justice in Mill' (2019a): 80-93. 
Utilitas 'Mill's Evolutionary Theory of Justice: Reflections on Persky' (2019b): published online.

VArouxakis, GeOrgios, Victorian Political Thought on France and the French (Basingstoke; Palgrave, 2002).

WINCH, DONALD, Wealth and Life: Essays on the Intellectual History of Political Economy in Britain, 1848 1914 (Cambridge: Cambridge University Press, 2009).

YUNKER, JAMES A., Review of Social Economy, 'Capital Management under Market Socialism' (1973) 32/2: 196-210.

Journal of Economic Issues, 'Post-Lange Market Socialism: An Evaluation of ProfitOriented Proposals' (1995) 29/3: 683-717.

Annals of Public and Cooperative Economy 'A Survey of Market Socialist Forms', (1975) 46: 131-162.

Polity, 'Would Democracy Survive under Market Socialism?', (1986), 18/4: 678-

695.

69-116.

Comparative Economic Studies, ‘A New Perspective on Market Socialism’, (1988) 30/2:

2001).

On the Political Economy of Market Socialism: Essays and Analyses (London: Routledge, 